\title{
Short-term effects of heavy metal and temperature stresses on the photo- physiology of Symbiodinium isolated from the coral Fungia repanda
}

\author{
MANJULA D. GHOORA ${ }^{1}$, SIVAJYODEE S. PILLY ${ }^{1}$, PRAMOD KUMAR CHUMUN ${ }^{2}$, SHOBHA JAWAHEER ${ }^{1, \bullet}$, \\ RANJEET BHAGOOLI ${ }^{1,2,3,4, \bullet \vee}$ \\ ${ }^{1}$ Department of Biosciences and Ocean Studies, Faculty of Science, University of Mauritius. Réduit 80837, Republic of Mauritius \\ vemail: shobha@uom.ac.mu \\ ${ }^{2}$ The Biodiversity and Environment Institute. Réduit, Republic of Mauritius. Tel.: +230-4037916, Fax.: +230-4656928, •vemail: r.bhagooli@uom.ac.mu \\ ${ }^{3}$ Pole of Research Excellence, Sustainable Marine Biodiversity Research Group, University of Mauritius. Réduit 80837, Republic of Mauritius \\ ${ }^{4}$ Institute of Oceanography and Environment (INOS), Universiti Malaysia Terengganu. 21030 Kuala Terengganu, Terengganu, Malaysia
}

Manuscript received: 2 May 2018. Revision accepted: 14 June 2018.

\begin{abstract}
Ghoora MD, Pilly SS, Chumun PK, Jawaheer S, Bhagooli R. 2018. Short-term effects of heavy metal and temperature stresses on the photo-physiology of Symbiodinium isolated from the coral Fungia repanda. Ocean Life 2: 11-20. This study aimed to investigate the effects of the heavy metals, copper, zinc and lead, on the photo-physiology of the symbiotic dinoflagellate Symbiodinium isolated from the coral Fungia repanda. Freshly isolated Symbiodinium found to belong to clade C were exposed to different concentrations of the three heavy metals for 3-hour and 18 -hour treatments at $28^{\circ} \mathrm{C}$ and $32^{\circ} \mathrm{C}$. The Pulse Amplitude Modulated (PAM) fluorometry technique was used to determine the maximum quantum yield $\left(F_{v} / F_{m}\right)$, relative maximum electron transport rate $\left(r E T R_{\max }\right)$ and maximum non-photochemical quenching $\left(N P Q_{\max }\right)$ of the photosystem II (PSII). An increase in non-photochemical quenching accompanied by a decrease in photosynthetic capacity was noted for copper at a concentration of $50 \mu \mathrm{g} / \mathrm{L}$ for both temperatures. The $F_{v} / F_{m}$ was not significantly affected by the $\mathrm{Zn}$ treatments. However, at $28^{\circ} \mathrm{C}$, isolates treated with $100 \mu \mathrm{g} / \mathrm{L} \mathrm{Zn}$ for 18 hours showed an increase in non-photochemical quenching accompanied by a decrease in photosynthetic capacity. $\mathrm{Pb}$ had the most profound effect on all of the isolates. The $F_{v} / F_{m}$ significantly decreased and an increase in $N P Q_{\max }$ was noted. The decrease of $r E T R_{\max }$ and increase in $N P Q_{\max }$ for the heavy metal bioassays under $32{ }^{\circ} \mathrm{C}$ were more significant than at $28{ }^{\circ} \mathrm{C}$. This study suggests that $\mathrm{Cu}(\geq 50 \mu \mathrm{g} / \mathrm{L}), \mathrm{Zn}(\geq 100 \mu \mathrm{g} / \mathrm{L})$ and $\mathrm{Pb}$ decrease the photosynthetic capacity of the Symbiodinium isolates from $F$. repanda especially more so with increasing temperatures.
\end{abstract}

Keywords: Fungia, heavy metal, photosynthetic parameters, Pulse Amplitude Modulated fluorometry, Symbiodinium, thermal stress

Abbreviations: PAM: Pulse Amplitude Modulated; $F_{v} / F_{m}$ : maximum quantum yield; $r E T R_{\max }$ : relative maximum electron transport rate; $N P Q_{\max }$ : maximum non-photochemical quenching; PSII: photosystem II; rpm: revolutions per minute; RLCs: rapid light curves; $F_{o}$ : initial fluorescence; $F_{m}$ : maximum fluorescence

\section{INTRODUCTION}

Although rising seawater temperature, one of the major indicators of global climate change (National Climatic Data Centre 2011), might exert damaging effects on the marine biota in the long term (from decades to centuries), chemical contaminants such as heavy metal pollution may pose more immediate threats to the coastal residents ( $\mathrm{Hu}$ et al. 2017). Release of heavy metals to the marine environment mainly results from atmospheric and river inputs, direct discharges, industrial dumping and sewage sludge, among the important contributors to metal pollution (Valavanidis and Vlachogianni 2010). At low concentrations, heavy metals are essential to the metabolism of the organisms, but at higher levels they may lead to toxicity (Phillips 1995; Sunda and Huntsman 1998; Pinto et al. 2003). Heavy metals are known to reduce photosynthesis by affecting the light harvesting complex, oxygen evolution complex, cytochrome complex, plastoquinone, plastocyanin, ferredoxin and $\mathrm{NADP}^{+}$(Baumann et al. 2009).

The marine environment undergoes rapid fluctuations in seawater temperature which may change the conditions necessary for optimum metabolism (Oukarroum et al.
2012). Field and laboratory studies on corals and their symbiotic associations have established a causal link between temperature stress and bleaching events (Lesser 1996) in symbiotic corals that build reefs. Exposure to sublethal temperatures (Iglesias-Prieto et al. 1992) leads to photoinhibition of photosynthetic processes in marine organisms. Elevated temperature has been found to cause damage to the photosystem II (Warner et al. 1999) and recovery of the D1 protein (Takahashi et al. 2009) which forms part of the water-splitting complex in photosystem II. Moreover, the Calvin-Benson cycle is compromised under high temperature exposures (Jones et al. 1998; Bhagooli and Yakovleva 2004; Bhagooli and Hidaka 2006) and the site of damage has been speculated to be the enzyme RuBisCO (Lesser 1996; Lilley et al. 2010). Temperature increase in aquatic systems has also been found to enhance the toxicity of some metals on algae (Cairns et al. 1975; Heugens et al. 2001) by increasing the rate of diffusion or active transport.

Environmental stresses pose a threat to the fragile coral reef ecosystems, which are hosts to a highly diverse group of dinoflagellate symbionts of the genus Symbiodinium (Baker 2003). These symbionts are responsible for the 
existence of the coral reefs as we know them (Stanley and Swart 1995) and contribute substantially to coral reef productivity. This study focused on the scleractinian coral Fungia, which is a genus tolerant to environmental stresses (Mattan-Moorgawa et al. 2011). Many studies used the chlorophyll $a$ fluorescence technique estimated by the pulse-amplitude-modulated (PAM) fluorometer to assess the photo-physiology of corals and/or their associated symbionts under heavy metal stress (Bielmyer et al. 2010; Gorbunov and Falkowski 2011) or temperature stress (Bhagooli and Hidaka 2002, 2006; Bhagooli and Yakovleva 2004) as individual stress factors. A few studies even looked at the interactive effects of heavy metal and temperature on photosynthetic physiology (Baumann et al 2009; Oukarroum et al. 2012) but Baumann et al. (2009) worked with macroalgae over a 14-day period and Oukarroum et al. (2012) worked with cultured microalgae over a 24-hour period. To the best of our knowledge, there is a dearth of information on the short-term effects of heavy metals assessed individually and in combination with temperature stress on the photosynthetic physiology of freshly-isolated symbionts of a thermally resistant coralFungia repanda. The main objective of the present study is thus to expose freshly isolated Symbiodinium of $F$. repanda to increasing concentrations of heavy metals namely $\mathrm{Cu}$, $\mathrm{Zn}$ and $\mathrm{Pb}$ for 3-hour and 18-hour treatments under two temperatures $-28^{\circ} \mathrm{C}$ and $32^{\circ} \mathrm{C}$ in order to assess the photosynthetic physiology of the organism in response to the stress conditions using PAM fluorometry to determine the three chlorophyll a fluorescence parameters-the maximum quantum yield $\left(F_{v} / F_{m}\right)$ of PSII, the maximum relative electron transport rate $\left(r E T R_{\max }\right)$ and the maximum non-photochemical quenching $\left(N P Q_{\max }\right)$.

\section{MATERIALS AND METHODS}

\section{Specimen collection and symbiont isolation}

Medium-sized scleractinian coral individuals of Fungia repanda (diameter $\sim 10 \mathrm{~cm}$ ) were collected at a depth of $\sim 2$ $\mathrm{m}$ at Trou aux Biches, one of the world-renowned beaches located on the northern coast of the island of Mauritius $\left(20.0350{ }^{\circ} \mathrm{S}, 57.5450{ }^{\circ} \mathrm{E}\right)$ (Figure 1). The reefs of Trou aux Biches harbor a diversity of coral species including Acropora, Alveopora, Echinopora, Favia, Favites, Fungia, Galaxea, Pavona, Pocillopora, Porites amongst various other genera (AIMS 2017).

The coral was allowed to recover from handling in a plastic container filled with seawater for 1 hour at ambient temperature $\left(25.0 \pm 1.0^{\circ} \mathrm{C}\right)$ prior to further processing. Symbiodinium cells were obtained from $F$. repanda by blasting the coral with filtered sea water (FSW) $(0.47 \mu \mathrm{m})$ using an oral hygiene device (Water Pik). The blasted tissue was then homogenized using a tissue grinder at 9500 $\mathrm{rpm}$. The homogenate was filtered twice, first with a coarse $(180 \mu \mathrm{m})$ and then a fine $(35 \mu \mathrm{m})$ filter mesh and subsequently centrifuged at $2000 \times \mathrm{x}$ for five minutes. The pellets were re-suspended with FSW before a second centrifugation at $1800 \times \mathrm{x}$ for ten minutes to obtain clean Symbiodinium pellets. A cell count was performed using the Neubauer Hemocytometer Chamber and $1 \mathrm{ml}$ of the isolated symbionts suspension was adsorbed onto $0.22 \mu \mathrm{m}$ Millipore filters $(\varnothing-13 \mathrm{~mm})$ using a syringe apparatus. Cell

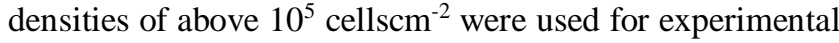
trials as these densities ensure reliable PAM measurements (Bhagooli and Hidaka 2004a).
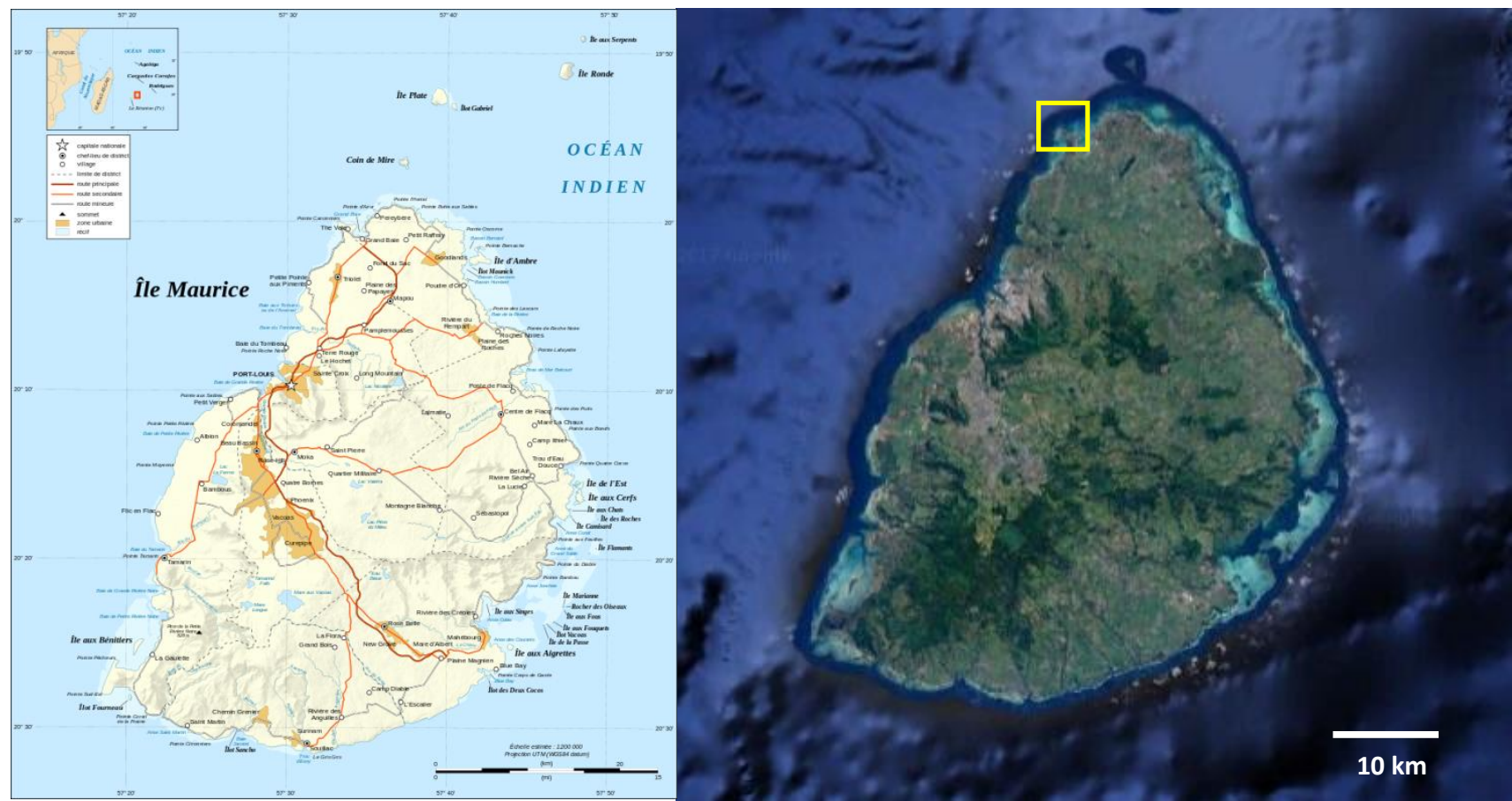

Figure 1. Mauritius and its aerial view showing the sampling site, Trou aux Biches 


\section{Experimental protocol}

In the laboratory, Symbiodinium cells were harvested on millipore filters and separately exposed to four different concentrations of the heavy metals $\mathrm{Cu}, \mathrm{Zn}$ and $\mathrm{Pb}$. For each heavy metal assay, the Symbiodinium was cultured under two temperature regimes, $28{ }^{\circ} \mathrm{C}$ and $32{ }^{\circ} \mathrm{C}$, and two exposure period, 3-h and 18-h. Each test was carried out in triplicate. These two temperatures were chosen to represent two conditions leading to non-bleaching and bleaching responses, respectively, in corals reported from Mauritian waters (Bhagooli and Taleb-Hossenkhan 2012; Mattanmoorgawa et al. 2012) and the Great Barrier Reef (Jones et al. 1998). Heavy metal test concentrations were prepared by dilution of standard solutions of $\mathrm{Cu}, \mathrm{Zn}$ and $\mathrm{Pb}(1000$ ppm) with sea water filtered through a $0.2 \mu \mathrm{m}$ membrane filter (Schleicher and Schuell Nitrocellulose Membrane Filters) to produce the following concentrations- $\mathrm{Cu}: 0,10$, 30 and $50 \mu \mathrm{g} / \mathrm{L} ; \mathrm{Zn}: 0,25,50$ and $100 \mu \mathrm{g} / \mathrm{L} ; \mathrm{Pb}: 0,10,30$ and $50 \mu \mathrm{g} / \mathrm{L}$. The concentrations were chosen based on the range of levels of heavy metals reported in coral reefs areas (e.g. Ali et al. 2011) and set toxic thresholds (ANZECC 1992). Five millilitres of each heavy metal solution was added to McCartney bottles followed by subsequent addition of 1 Millipore filter with adsorbed symbionts per vial. The McCartney bottles were then immersed in two waterbaths, one set at $28{ }^{\circ} \mathrm{C}$ and the other one at $32{ }^{\circ} \mathrm{C}$. The treatments were illuminated by a light source of $200 \mu \mathrm{mol}$ $\mathrm{m}^{-2} \mathrm{~s}^{-1}$ measured by a light meter (Hagner Digital Luxmeter, EC1-Y) during the 3-h and 18-h stress.

\section{Chlorophyll fluorescence measurements}

Chlorophyll fluorescence was measured using a Pulse Amplitude Modulated (PAM) fluorometer (DIVING-PAM, Heinz Waltz GmbH, Germany). The initial fluorescence $\left(F_{o}\right)$ was determined by applying a weak pulse-modulated measuring light $\left(<0.1 \mu\right.$ mol quanta $\left.\mathrm{m}^{-2} \mathrm{~s}^{-1}\right)$ when the PSII reaction centres are open. The maximum fluorescence $\left(F_{m}\right)$ was determined after applying a saturating pulse (> 6000 $\mu \mathrm{mol}$ quanta $\mathrm{m}^{-2} \mathrm{~s}^{-1}$ ) when the reaction centres are closed. The ratio of the change in fluorescence to maximum fluorescence $\left(\left[F_{m}-F_{o}\right] / F_{m}\right)$ gives the dark-adapted photosynthetic parameter $F_{v} / F_{m}$, which is a good proxy of the maximum quantum yield of PSII (Genty et al. 1989). Samples were dark-adapted for 15 minutes prior to measurement. After the dark-adapted measurement, the samples were light adapted for 5 minutes, followed by $30 \mathrm{~s}$ dark period, and initial and maximum fluorescence $\left(F_{o}{ }^{\prime}\right.$ and $F_{m}{ }^{\prime}$ respectively) were determined again. The product of the ratio of change in fluorescence to maximum fluorescence of light-adapted samples $\left(\left[F_{m}{ }^{\prime}-F_{o}{ }^{\prime}\right] / F_{m}{ }^{\prime}\right)$ (also known as the effective quantum yield) and the photosynthetically active radiation (PAR) gives the parameter relative Electron Transport Rate (rETR). The non-photochemical quenching $(N P Q)$ parameter, which regulates dissipation of excess energy in the form of heat, is derived from the ratio of change in maximum fluorescence from the dark-adapted to the light-adapted stage, to the maximum fluorescence of the illuminated sample $\left(N P Q=\left[F_{m}-F_{m}^{\prime}\right] / F_{m}{ }^{\prime}\right)$ (Bilger and Björkmann 1990).

The $r E T R$ and the $N P Q$ were derived from the rapid light curves (RLCs) obtained after light adapting the samples. The RLCs determines the physiological flexibility of the symbionts to adapt their photosynthetic apparatus to rapidly changing light intensities. Rapid irradiances occurred at an interval of every $10 \mathrm{~s}$ and gave fluorescence measurements which were fitted as an exponential decay curve. The $r E T R_{\max }$ was obtained by fitting $r E T R$ curves in the Sigma Plot software using the Platt et al. (1980) equation. $N P Q_{\max }$ represents the highest non-photochemical quenching value.

\section{Symbiodinium isolation, DNA extraction and clade identification}

Coral tissues were removed using a waterpik and filtered seawater (FS, $0.45 \mu \mathrm{m})$. The blastate was centrifuged for $10 \mathrm{~min}$ at $4000 \mathrm{rpm}$, washed with filtered seawater and centrifuged again to pellet the Symbiodinium cells. The pellet was suspended in $1 \mathrm{ml}$ of FS. Following centrifugation for $5 \mathrm{~min}$ at $4000 \mathrm{rpm}$ the pellet was resuspended with $1 \%$ sodium dodecyl sulfate (SDS) and DNA isolation buffer (0.4 M NaCl; $50 \mathrm{mM}$ EDTA, $\mathrm{pH} 8)$, vortexed, treated for $1-2 \mathrm{hrs}$ at $65^{\circ} \mathrm{C}$ and stored at room temperature for later analyses. DNA extraction, was carried out using slightly modified method of Rowan and Powers (1991). Proteinase-K was added to the Symbiodinium suspension and incubated for $2-3 \mathrm{hrs}$ at $55^{\circ} \mathrm{C} .64 \mu \mathrm{l}$ of $5 \mathrm{M}$ $\mathrm{NaCl}$ was added followed by $60 \mu \mathrm{l}$ of $10 \%$ cetyltrimethylammonium bromide $(\mathrm{CTAB})$ and was toped up to $600 \mu \mathrm{l}$ with sterile distilled water. The lysate was then heated for $30 \mathrm{~min}$ at $65^{\circ} \mathrm{C}$ followed by addition of $600 \mu \mathrm{l}$ of chloroform. The lysate was subject to chloroform extraction once and phenol extraction twice. $900 \mu \mathrm{l}$ of cold ethanol was then added followed by $45 \mu \mathrm{l} 3 \mathrm{M}$ Sodium Acetate $(\mathrm{NaOAc})$. The DNA was precipitation at $-20^{\circ} \mathrm{C}$ overnight and excess chloroform was washed with $70 \%$ ethanol. The DNA was then air dried and re-suspended in $50 \mu 1 \mathrm{TE}$ buffer. Polymerase chain reaction (PCR) was done using Symbiodinium specific primers ss3z and ss5z that anneal to the 18S-rDNA region of the Symbiodinium DNA. Restriction digest was performed by incubating the PCR product for 2 hours with Taq I enzyme. The banding pattern of the RFLP was then visualize in agarose gel.

\section{Statistical analyses}

Chlorophyll fluorescence data was arcsine transformed prior to statistical analyses. Multivariate analysis of variance (ANOVA) was carried out using the statistical software STATISTICA version 10.0 to compare the effects of the heavy metals $(\mathrm{Cu}, \mathrm{Zn}$ and $\mathrm{Pb})$ and their respective concentrations, temperatures $\left(28^{\circ} \mathrm{C}\right.$ and $\left.32^{\circ} \mathrm{C}\right)$ and exposure times (3-h and 18-h) per se and in combination on the photosynthetic parameters, $F_{v} / F_{m}, r E T R_{\max }$ and $N P Q_{\max }$. Differences between groups were determined by the Post Hoc Tukey HSD test. 


\section{RESULTS AND DISCUSSION}

Genotyping results showed that $F$. repanda harboured the Symbiodinium Clade C (Figure 2). An increase in temperature, heavy metal concentrations, and exposure time reduced the maximum quantum yield $\left(F_{v} / F_{m}\right)$ of the symbionts significantly $(\mathrm{P}<0.05)$. The maximum nonphotochemical quenching $\left(N P Q_{\max }\right)$ was increased significantly $(\mathrm{P}<0.001)$ by temperature, heavy metal concentration and exposure time. However, no marked difference $(\mathrm{P}>0.05)$ was noted across the three heavy metals. The $r E T R_{\max }$ remained invariant $(\mathrm{P}>0.05)$ under temperature stress but was significantly reduced by the heavy metals and their concentrations and exposure time. Interaction of stress factors, evaluated by the multivariate ANOVA analyses had variable effects on the photosynthetic parameters as shown in Table 1.

\section{Effects of $\mathrm{Cu}$}

Figure 3 shows the variation of the three fluorescencebased parameters, $F_{v} / F_{m}, r E T R_{\max }$ and $N P Q_{\max }$ with $\mathrm{Cu}$ concentrations over three and eighteen-hour treatments. Zooxanthellae isolated from $F$. repanda had initial $F_{v} / F_{m}$ values of $0.593 \pm 0.011$. At $28{ }^{\circ} \mathrm{C}$, no change in $F_{v} / F_{m}$ was noted $(\mathrm{P}>0.05)$, the light-adapted parameters were affected significantly; $50 \mu \mathrm{g} / \mathrm{L}$ copper reduced the $r E T R_{\max }$ significantly for all isolates $(\mathrm{P}<0.001$ for $3 \mathrm{~h}$; $\mathrm{P}<0.01$ for $18 \mathrm{~h})$ and increased the $N P Q_{\max }$ for the $18 \mathrm{~h}$ treatment $(\mathrm{P}<$ 0.01). The combined effects of copper and high temperature stresses $\left(32^{\circ} \mathrm{C}\right)$ considerably reduced the photosynthetic outputs of PSII. Although $10 \mu \mathrm{g} / \mathrm{L}$ copper did not affect the photosynthetic parameters measured, a significant reduction in $r E T R_{\max }(\mathrm{P}<0.001)$ during the $18 \mathrm{~h}$ treatment was evident with $30 \mu \mathrm{g} / \mathrm{L} \mathrm{Cu}$. The highest copper concentration used $(50 \mu \mathrm{g} / \mathrm{L})$ caused marked decreased in $F_{v} / F_{m}(\mathrm{P}<0.05$ for $3 \mathrm{~h} ; \mathrm{P}<0.01$ for $18 \mathrm{~h})$ and $r E_{T R} R_{\max }(\mathrm{P}<$
0.01 for $18 \mathrm{~h}$; no change for $3 \mathrm{~h}$ ) and significant increase in $N P Q_{\max }(\mathrm{P}<0.001$ for both $3 \mathrm{~h}$ and $18 \mathrm{~h})$.

\section{Effects of $\mathbf{Z n}$}

$\mathrm{Zn}$ exposure on isolated Symbiodinium (Figure 4) showed no significant change in $F_{v} / F_{m}$ for all treatments. However, the $r E T R_{\max }$ was significantly reduced at $28^{\circ} \mathrm{C}$ when the symbionts were treated with $100 \mu \mathrm{g} / \mathrm{L}$ zinc for 18 h $(\mathrm{P}<0.05)$. An associated increase in $N P Q_{\max }(\mathrm{P}<0.01)$ was noted for the same treatment. At $32^{\circ} \mathrm{C}$, zinc concentrations of $50 \mu \mathrm{g} / \mathrm{L}$ and $100 \mu \mathrm{g} / \mathrm{L}$ caused significant increase in $N P Q_{\max }(\mathrm{P}<0.001$ for $50 \mu \mathrm{g} / \mathrm{L} ; \mathrm{P}<0.01$ for $100 \mu \mathrm{g} / \mathrm{L})$ but not the other measured photosynthetic parameters.

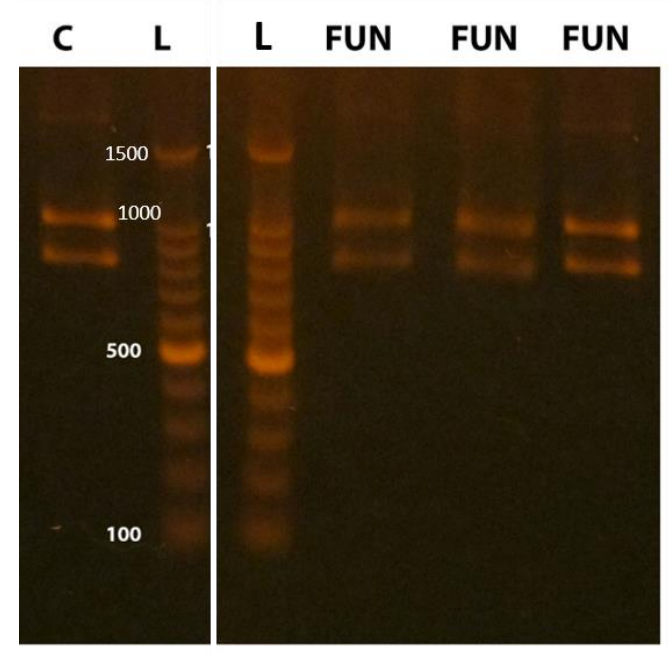

Figure 2. Restriction fragment length polymorphism (RFLP) of Symbiodinium Clade harbored by $F$. repanda. C-clade C; L-DNA ladder; FUN-F. repanda

Table 1. Summary of multivariate ANOVA analyses testing the effect of temperature $\left(28^{\circ} \mathrm{C}\right.$ and $\left.32^{\circ} \mathrm{C}\right)$, heavy metals $(\mathrm{Cu}, \mathrm{Zn}$ and $\mathrm{Pb})$ and their respective concentrations ( $\mathrm{Cu}$ and $\mathrm{Pb}: 0,10,30$ and $50 \mu \mathrm{g} / \mathrm{L} ; \mathrm{Zn}: 0,25,50$ and $100 \mu \mathrm{g} / \mathrm{L}$ ) and exposure time (3h and $18 \mathrm{~h}$ ) individually and in combination (s), on $F_{v} / F_{m}, N P Q_{\max }$ and $r E T R_{\max }$ ). Significant differences are indicated in red. [Abbreviations: Temp: temperature; HM: heavy metals; Conc: concentration; DF: degree of freedom; MS: mean square; F: variance ratio; P: probability value] $(\mathrm{n}=3)$

\begin{tabular}{|c|c|c|c|c|c|c|c|c|c|c|c|c|}
\hline \multirow{2}{*}{ Source of variation } & \multicolumn{4}{|c|}{$\boldsymbol{F}_{v} / \boldsymbol{F}_{m}$} & \multirow[b]{2}{*}{ DF } & \multicolumn{3}{|c|}{$N P Q_{\max }$} & \multirow[b]{2}{*}{ DF } & \multicolumn{3}{|c|}{$r E T R_{\max }$} \\
\hline & DF & MS & $\mathbf{F}$ & $\mathbf{P}$ & & MS & $\mathbf{F}$ & $\mathbf{P}$ & & MS & $\mathbf{F}$ & $\mathbf{P}$ \\
\hline Temp & 1 & 0.001 & 4 & 0.037 & 1 & 0.018 & 29.66 & 0.000 & 1 & 0.004 & 3.70 & 0.057 \\
\hline $\mathrm{HM}$ & 2 & 0.001 & 9 & 0.000 & 2 & 0.001 & 1.08 & 0.341 & 2 & 0.004 & 4.35 & 0.015 \\
\hline Conc & 3 & 0.005 & 35 & 0.000 & 3 & 0.038 & 63.76 & 0.000 & 3 & 0.027 & 25.88 & 0.000 \\
\hline Time & 2 & 0.005 & 36 & 0.000 & 2 & 0.039 & 65.51 & 0.000 & 2 & 0.223 & 217.36 & 0.000 \\
\hline Temp*HM & 2 & 0.000 & 0 & 0.890 & 2 & 0.003 & 5.59 & 0.005 & 2 & 0.008 & 7.33 & 0.001 \\
\hline Temp*Conc & 3 & 0.000 & 1 & 0.512 & 3 & 0.001 & 1.47 & 0.226 & 3 & 0.001 & 1.20 & 0.312 \\
\hline HM*Conc & 6 & 0.000 & 1 & 0.536 & 6 & 0.000 & 0.68 & 0.663 & 6 & 0.002 & 1.68 & 0.131 \\
\hline Temp*Time & 2 & 0.000 & 2 & 0.120 & 2 & 0.005 & 7.93 & 0.001 & 2 & 0.007 & 6.88 & 0.001 \\
\hline HM*Time & 4 & 0.000 & 2 & 0.047 & 4 & 0.002 & 3.93 & 0.005 & 4 & 0.008 & 7.46 & 0.000 \\
\hline Conc*Time & 6 & 0.000 & 2 & 0.172 & 6 & 0.011 & 18.98 & 0.000 & 6 & 0.009 & 8.69 & 0.000 \\
\hline Temp $*$ HM ${ }^{*}$ Conc & 6 & 0.000 & 0 & 0.933 & 6 & 0.000 & 0.71 & 0.640 & 6 & 0.005 & 5.36 & 0.000 \\
\hline Temp*HM*Time & 4 & 0.000 & 0 & 0.899 & 4 & 0.002 & 2.65 & 0.036 & 4 & 0.008 & 7.67 & 0.000 \\
\hline Temp*Conc*Time & 6 & 0.000 & 0 & 0.950 & 6 & 0.001 & 2.16 & 0.050 & 6 & 0.002 & 1.92 & 0.081 \\
\hline HM*Conc ${ }^{*}$ Time & 12 & 0.000 & 0 & 0.993 & 12 & 0.001 & 2.45 & 0.006 & 12 & 0.003 & 2.55 & 0.004 \\
\hline Temp*HM*Conc*Time & 12 & 0.000 & 0 & 0.998 & 12 & 0.001 & 1.39 & 0.179 & 12 & 0.004 & 3.55 & 0.000 \\
\hline
\end{tabular}



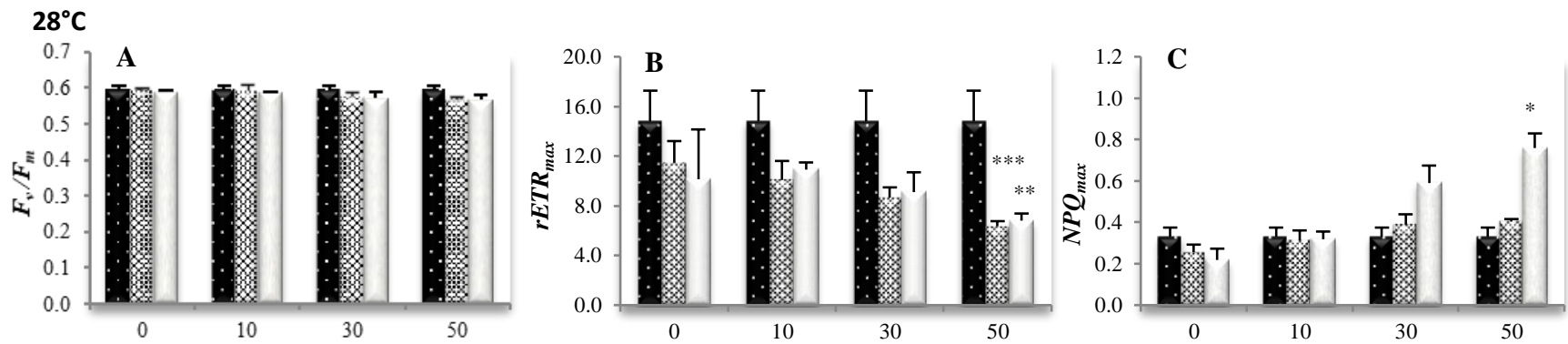

$32^{\circ} \mathrm{C}$
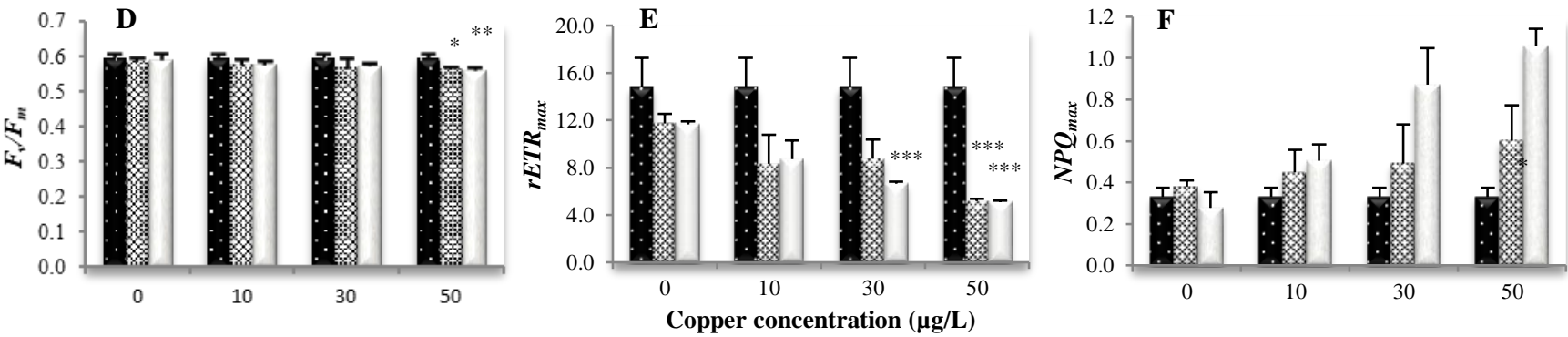

- Initial 3 hours $\sqcup 18$ hours

Figure 3. Maximum quantum yield of PSII $\left(\mathrm{F}_{\mathrm{v}} / \mathrm{F}_{\mathrm{m}}\right)$, maximum relative electron transport rate (rETR $\left.\max \right)$ and non-photochemical quenching $\left(\mathrm{NPQ}_{\max }\right)$ of zooxanthellae isolated from F. repanda under $\mathrm{Cu}$ treatments at $28^{\circ} \mathrm{C}(\mathrm{A}, \mathrm{B}$ and $\mathrm{C})$ and $32^{\circ}$ (D, E and F). Note: * represents $\mathrm{P}<0.05$, ** represents $\mathrm{P}<0.01$ and $* * *$ represents $\mathrm{P}<0.001$ between the treatment and initial. Data are represented as mean \pm standard deviation $(\mathrm{n}=3)$.

$28^{\circ} \mathrm{C}$
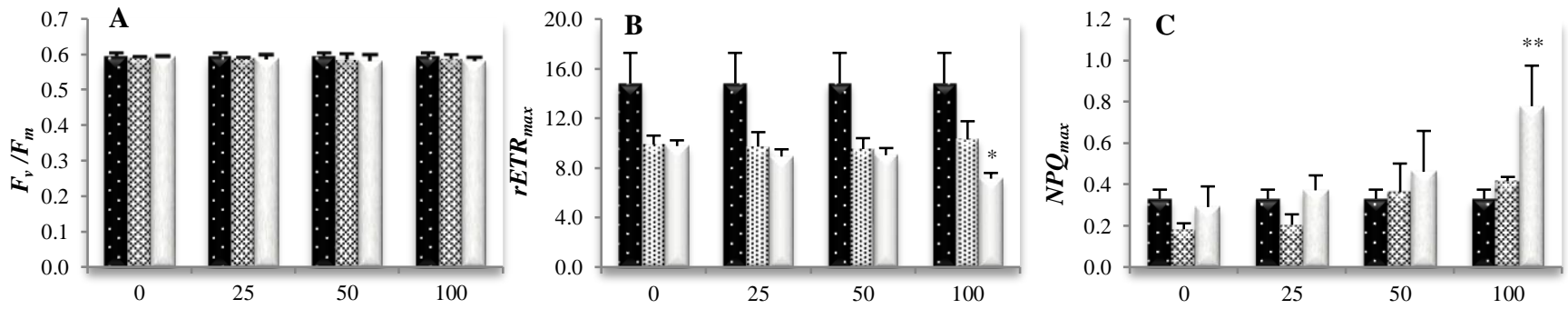

$32^{\circ} \mathrm{C}$
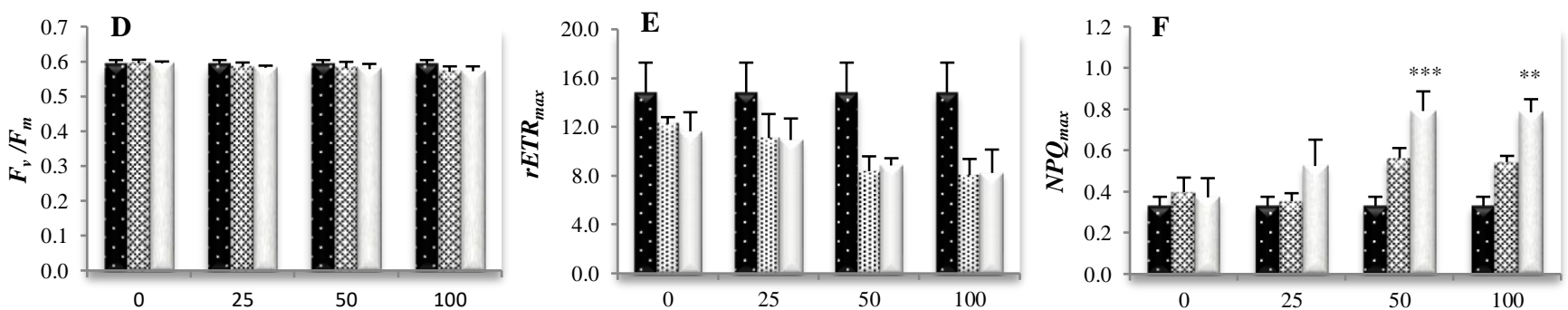

Zinc concentration $(\mu \mathrm{g} / \mathrm{L})$

a Initial 3 hours $\sqcup 18$ hours

Figure 4. Maximum quantum yield of PSII $\left(F_{v} / F_{m}\right)$, maximum relative electron transport rate $\left(r E T R_{\max }\right)$ and non-photochemical quenching $\left(N P Q_{\max }\right)$ of zooxanthellae isolated from $F$. repanda under $\mathrm{Zn}$ treatments at $28^{\circ} \mathrm{C}(\mathrm{A}, \mathrm{B}$ and $\mathrm{C})$ and $32^{\circ}(\mathrm{D}, \mathrm{E}$ and $\mathrm{F})$. Note: * represents $\mathrm{P}<0.05$, ** represents $\mathrm{P}<0.01$ and $* * *$ represents $\mathrm{P}<0.001$ between the treatment and initial. Data are represented as mean \pm standard deviation $(\mathrm{n}=3)$. 

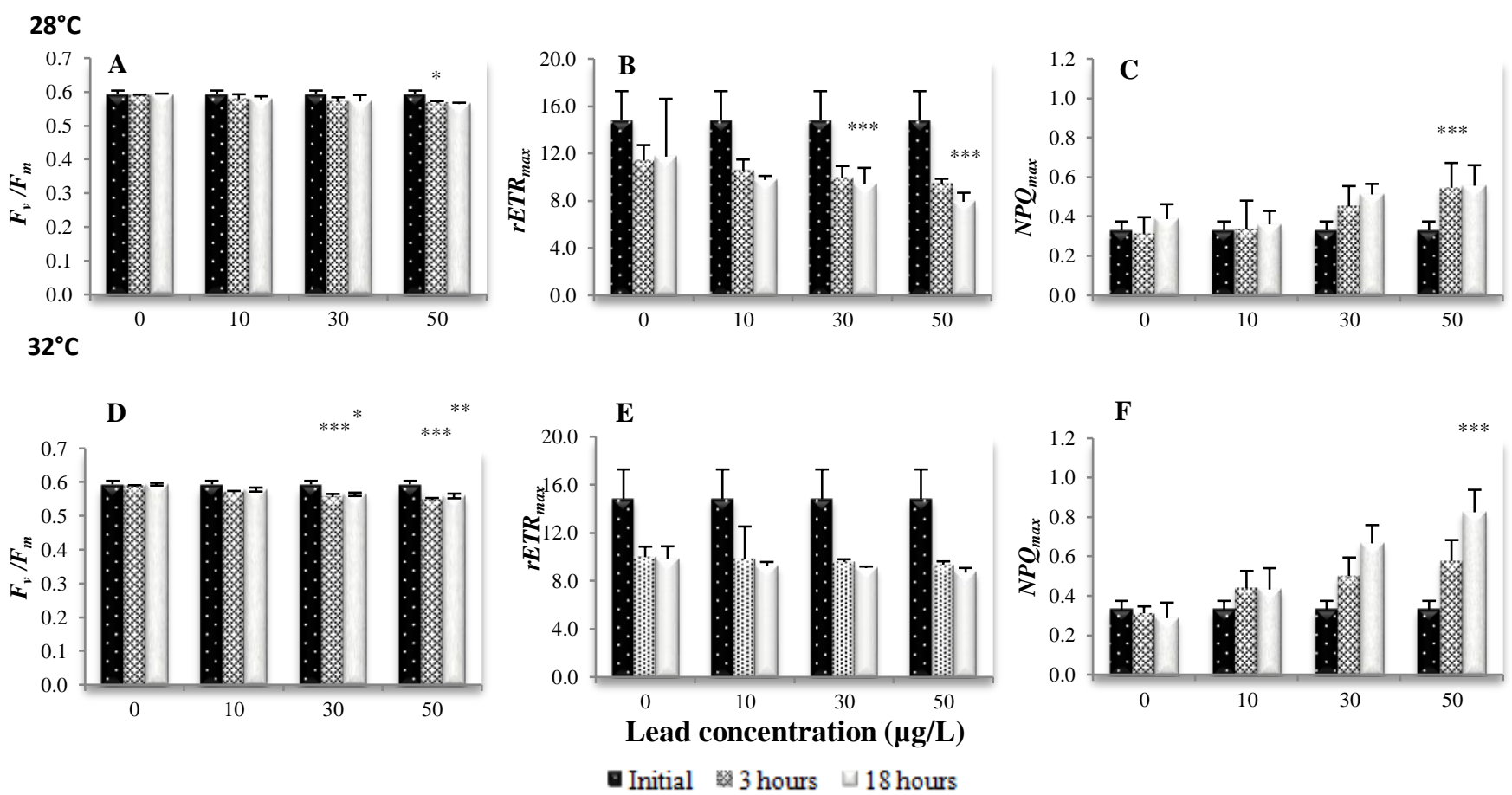

Figure 5. Maximum quantum yield of PSII $\left(F_{v} / F_{m}\right)$, maximum relative electron transport rate $\left(r E T R_{\max }\right)$ and non-photochemical quenching $\left(N P Q_{\max }\right)$ of zooxanthellae isolated from $F$. repanda under $\mathrm{Pb}$ treatments at $28^{\circ} \mathrm{C}(\mathrm{A}, \mathrm{B}$ and $\mathrm{C})$ and $32^{\circ}(\mathrm{D}, \mathrm{E}$ and $\mathrm{F})$. Note: * represents $\mathrm{P}<0.05$, ** represents $\mathrm{P}<0.01$ and $* * *$ represents $\mathrm{P}<0.001$ between the treatment and initial. Data are represented as mean \pm standard deviation $(\mathrm{n}=3)$

\section{Effects of $\mathbf{P b}$}

$\mathrm{Pb}$ reduced the photosynthetic capacity of the isolated Symbiodinium by affecting all the photosynthetic parameters monitored (Figure 5). A pronounced decrease was noted in $F_{v} / F_{m}$ over both temperature treatments (28 ${ }^{\circ} \mathrm{C}$ and $32{ }^{\circ} \mathrm{C}$ ). While the $F_{v} / F_{m}$ value of the $50 \mu \mathrm{g} / \mathrm{L}$ lead treatment over $3 \mathrm{~h}$ was significantly reduced $(\mathrm{P}<0.05)$ at $28^{\circ} \mathrm{C}$, marked reduction was noted as from $30 \mu \mathrm{g} / \mathrm{L}$ for the same parameter at $32{ }^{\circ} \mathrm{C}$; the symbionts exposed for $3 \mathrm{~h}$ and $18 \mathrm{~h}$ under $30 \mu \mathrm{g} / \mathrm{L}$ and $50 \mu \mathrm{g} / \mathrm{L}$ lead treatments at $32^{\circ} \mathrm{C}$ had significantly lower $F_{v} / F_{m}$ values $(30 \mu \mathrm{g} / \mathrm{L}$ : $\mathrm{P}<$ 0.001 for $3 \mathrm{~h}, \mathrm{P}<0.05$ for $18 \mathrm{~h} ; 50 \mu \mathrm{g} / \mathrm{L}: \mathrm{P}<0.001$ for $3 \mathrm{~h}$, $\mathrm{P}<0.01$ for $18 \mathrm{~h}$ ). The $r E T R_{\max }$ was significantly reduced after $18 \mathrm{~h}$ at lead concentrations of $30 \mu \mathrm{g} / \mathrm{L}$ and $50 \mu \mathrm{g} / \mathrm{L}$ for the $28{ }^{\circ} \mathrm{C}$ treatment $(\mathrm{P}<0.001)$ but not for $32{ }^{\circ} \mathrm{C}$. However, for treatments at both temperatures $\left(28{ }^{\circ} \mathrm{C}\right.$ and $\left.32{ }^{\circ} \mathrm{C}\right)$ showed a significant increase in $N P Q_{\max }(\mathrm{P}<0.001$ for $3 \mathrm{~h}$ at $28{ }^{\circ} \mathrm{C}, \mathrm{P}<0.001$ for $18 \mathrm{~h}$ at $32^{\circ} \mathrm{C}$ ).

\section{Discussion}

A $\mathrm{Cu}$ concentration of $50 \mu \mathrm{g} / \mathrm{L}$ did not result in any significant changes in $F_{\sqrt{ }} / F_{m}$, however, a decrease in $r E T R_{\max }$ accompanied by an increase in $N P Q_{\max }$ was recorded within $18 \mathrm{hrs}$ of exposure. This suggests that 50 $\mu \mathrm{g} / \mathrm{L} \mathrm{Cu}$ decreased the photosynthetic capacity of the Symbiodinium and the excess energy was effectively dissipated. This is consistent with Yruela et al. (1992) who noted that $\mathrm{Cu}$ inhibits electron transfer at the level of pheophytin $\mathrm{Q}_{\mathrm{A}}-\mathrm{Fe}$ domain of the PSII reaction centre and
Han et al. (2008) who noted no significant change in photosynthetic yield at $\mathrm{Cu}$ concentrations $25-50 \mu \mathrm{g} / \mathrm{L}$ but a higher $\mathrm{Cu}$ concentration of $250 \mu \mathrm{g} / \mathrm{L}$ did reduce the $F_{v} / F_{m}$ significantly. A large body of research has shown that $\mathrm{Cu}$ is toxic to the photophysiology of marine organisms and cause damage to several target sites along the photosynthetic pathway (Parales-Vela 2007; Han et al. 2008; Bielmyer et al. 2010; Connan and Stengel 2011; Oukarroum et al. 2012). As toxicity is generally considered to be dose-dependent, a high $\mathrm{Cu}$ concentration is expected to cause decline in the photosynthetic yield. Moreover, toxicity is linked to the sensitivity of the test organisms since $\mathrm{Cu}$ concentration as low as $4 \mu \mathrm{g} / \mathrm{L}$ has been found to reduce the quantum yield in algal symbionts of Pocillopora damicornis as reported by Bielmyer et al. (2010). Kuzminov et al. (2013) investigated $\mathrm{Cu}$ toxicity over several days in a cultured Symbidinium (CCMP 2467) isolated from the coral Stylophora pistillata. They reported no significant change in $\mathrm{F}_{\mathrm{v}} / \mathrm{F}_{\mathrm{m}}$ and slight but not significant increase in maximum rate of photosynthetic electron transport (Pmax) up to 2 days of exposure to $50 \mu \mathrm{M} \mathrm{Cu}$ at $25^{\circ} \mathrm{C}$. However, after 3 days exposure, was observed significant decline in both $\mathrm{F}_{\mathrm{v}} / \mathrm{F}_{\mathrm{m}}$ and Pmax. They also reported that the time of electron transport between photosystems ( $\left.\tau_{\text {PSII-PSI }}\right)$ increased significantly within $12 \mathrm{hrs}$ of treatment. It is noteworthy that in higher plants such as Arabidopsis thaliana, a significant increase in ETR after exposure to $\mathrm{Cu}$ concentrations of $50-100 \mu \mathrm{g} / \mathrm{L}$ was observed (Martínez-Peñalver et al. 2012) suggesting that 
$\mathrm{Cu}$ which is a micronutrient may have been limiting in the multicellular organism.

A significant reduction in the $r E T R_{\max }$ was recorded within $18 \mathrm{hrs}$ of exposure to $\mathrm{Zn}$ which is in line with other investigations on the effect of $\mathrm{Zn}$ on photosynthesis carried out by many authors (Davies and Sleep 1979; Tripathy and Mohanty 1980; El-Sheekh 1993). Experiment using the $\mathrm{O}_{2-}$ evolution method has shown that $\mathrm{Zn}$ inhibits the photosynthetic electron transport through PSII (Tripathy and Mohanty 1980) and this corresponds with the results of the present study where $\mathrm{Zn}$ has been shown to exert its effects at the oxidizing $\left(\mathrm{H}_{2} \mathrm{O}\right.$-splitting) side of PSII, possibly inhibiting the manganese complex (Miller and Cox 1983; Van Assche and Clijsters 1986). Baker et al. (1982) proposed a second site for $\mathrm{Zn}^{2+}$ action in the electron transfer chain between the PSII and the PSI and this has been attributed to plastoquinone (Mohanty et al. 1989). This is in line with the observed decrease in $r E T R_{\max }$. Though the $F_{v} / F_{m}$ did not vary significantly, it has been proposed that $F_{v} / F_{m}$ is not sensitive to $\mathrm{Zn}$ and hence it may not be a good indicator of $\mathrm{Zn}$ stress (Joshi and Mohanty 2004). Baumann et al. (2009) reported significant reduction in yield of macroalgae when exposed to $\mathrm{Zn}$ concentration of $10 \mu \mathrm{g} / \mathrm{L}$ after 4 days. In the latter study, $\mathrm{Zn}$ was reported to irreversibly bind to the test macroalgal species, causing death of the organisms which was confirmed by $F_{v} / F_{m}$ values of zero. Kuzminov et al. (2013) reported $\mathrm{Zn}$ toxicity in a cultured Symbidinium and found no significant change in $F_{v} / F_{m}$ and but significant increase in maximum rate of photosynthetic electron transport (Pmax) up to 2 days of exposure to $100 \mu \mathrm{M} \mathrm{Zn}$ at $25^{\circ} \mathrm{C}$. After 3 days exposure significant decline in both $\mathrm{F}_{\mathrm{v}} / \mathrm{F}_{\mathrm{m}}$ and Pmax was observed.

Studies have reported that $\mathrm{Pb}$ stress can cause inhibition of photosynthesis at the level of the light harvesting complexes of PSI and PSII (Miles et al. 1972) and photosynthetic reduction cycle (Stiborova et al. 1986). Moreover, PSII has been found to be more sensitive to $\mathrm{Pb}$ than PSI. Pb inhibition site is located at the donor side of PSII, between the oxygen-evolving complex and the reaction centre of PSII (Joshi and Mohanty 2004). This is in accordance with a decrease in $r E T R_{\max }$ with increasing concentration of $\mathrm{Pb}$. While in the present study $F_{v} / F_{m}$ of Symbiodinium was severely reduced when exposed to a $\mathrm{Pb}$ concentration of $50 \mu \mathrm{g} / \mathrm{L}$, Baumann et al. (2009) reported $\mathrm{Pb}$ to be one of the least toxic among 5 metals including $\mathrm{Cu}$ and $\mathrm{Zn}$. In the latter study, $\mathrm{Pb}$ caused no reduction in fluorescence yield of 7 species of macroalgae at $10 \mu \mathrm{g} / \mathrm{L}$ possibly because the macroalgae were tolerant to moderately high $\mathrm{Pb}$ concentration (Strömgren 1980; Lamai et al. 2005). However, Hussain et al. (2006) found drastic reduction in yield parameters when mash plants were exposed to $20-40 \mathrm{mg} / \mathrm{L} \mathrm{Pb}$. Reduction in photosynthesis in algae by $\mathrm{Pb}$ has also been reported by Woolery and Lewin (1976). Extensive inhibition of photosynthetic electron transport was observed when isolated chloroplasts were exposed to $2.4 \mathrm{mM} \mathrm{Pb}$ for a few minutes (Miles et al. 1972) and this corresponds to the effects of $\mathrm{Pb}$ in our study. As a result, the system significantly increased its nonphotochemical quenching to safely harness the excitation energy. Kuzminov et al. (2013) documented Pb toxicity in a cultured Symbidinium and reported no significant change in $\mathrm{F}_{\mathrm{v}} / \mathrm{F}_{\mathrm{m}}$ up to 3 days of exposure to $50 \mu \mathrm{M} \mathrm{Pb}$ at $25^{\circ} \mathrm{C}$ but slight decrease in maximum rate of photosynthetic electron transport (Pmax) up to 2 days of exposure. After 4 days exposure a significant decline in both $\mathrm{F}_{\mathrm{v}} / \mathrm{F}_{\mathrm{m}}$ and Pmax was observed. However, $\tau_{\text {PSII-PSI }}$ was the first parameter to be affected.

Under stress conditions such as combined heavy metal and thermal stress, the higher capacity for nonphotochemical quenching helps to provide protection to the photosynthetic organism. In the present study, all heavy metal treatments carried out at the elevated temperature $\left(32^{\circ} \mathrm{C}\right)$ recorded significantly high $N P Q_{\max }$. A proposed photoprotection mechanism involves the inter-conversion between the two pigments diatoxanthin and diadinoxanthin (Ting and Owens 1993). Ruban et al. (2004) demonstrated that $N P Q$ is tightly correlated to the presence of diatoxanthin and that the triggering key factor was the proton gradient across the thylakoid membranes. It is likely the alternative sources of protons such as the PS I cyclic electron transfer and/or chlororespiration are important in generating the proton gradient sufficient to trigger $N P Q$. Excess energy dissipation in the form of heat prevents the formation of reactive oxygen species which can induce lipid peroxidation and destruction of membrane structure and function. Both excess essential and non-essential metals, and elevated temperature are known to affect algal and coral, among other coastal species, physiology, metabolism and growth (El-Sarraf and Taha 1995; Bertrand and Poirier 2005; Mitchelmore et al. 2007; Baumann et al. 2009; Bielmyer et al. 2010; Main et al. 2010; Connan and Stengel 2011; Kuzminov et al. 2013). It is noteworthy that along with heavy metal stresses, the combined effects of temperature pose a greater threat on marine life forms (Cairns et al. 1978; Sokolova and Lannig 2008; Oukarroum et al. 2012). As noted by Oukarroum et al. (2012), heavy metal toxicity on photosynthetic performance is temperature-dependent, consistent with the present study. However, research carried out by Cairns et al. (1978) on four algal species revealed differential effects of heavy metal toxicity to temperature most probably due to different culturing methods of the algae, representing distinctly different habitats. The Mauritian waters is not spared from both metal contamination (Daby 2006) and elevated thermal anomalies (Mattan-Moorgawa et al. 2012; Bhagooli and Taleb-Hossenkhan 2012; Bhagooli and Sheppard 2012).

Time of stress under heavy metals significantly influenced the photosynthetic parameters in this study. Algal cells can accumulate heavy metals when exposed at high concentrations and these heavy metals can interfere with photosynthesis. However, specific responses of a given heavy metal on photosynthesis vary among species, thus broad generalization cannot be made about the combined effects of heavy metal exposure and time. The severity of the stress response depends on the exposure time as well as the concentration of heavy metals. Mitchelmore et al. (2007) showed that the coral Pocillopora damicornis could accumulate $\mathrm{Cu} 3$-fold and 
30 -fold at 5 and $50{\mu \mathrm{gl}^{-1}}^{1}$, respectively, after $4 \mathrm{~d}$ of exposure, with the in hospite Symbiodinium accumulating 1.5-fold of $\mathrm{Cu}$ in $5 \mu \mathrm{gl}^{-1}$ treatment higher than that in the control. Bielmyer et al. (2010) investigated the effect of exposure of $\mathrm{Cu}$ on the coral A. cervicornis for 5 weeks and observed that $\mathrm{Cu}$ exposure and accumulation may affect the symbiont by reducing $\mathrm{CO}_{2}$ available for photosynthesis. Kuzminov et al. (2013) also reported exposure timedependent toxicity of essential and non-essential metals along with differential photophysiological responses to the metals of cultured Symbiodinium. However, sensitivity to heavy metals may vary with the organism's physiology and hence, it is important to understand the mechanisms of action of these heavy metals to better evaluate the effects of heavy metal stress. It is also noteworthy that the accumulation of heavy metals for an effective concentration resulting in significant photophysiological changes may be time-dependent and thus short-term exposures in hours may need to be extended to days of exposures to be able to thoroughly evaluate impacts of heavy metals on Symbiodinium.

Rise in the surface sea water temperature is expected to cause mass bleaching events leading to 'extinction' of some coral reefs in Mauritius and the 'extinction dates' have been suggested to occur between the years 2025-2070 based on the bleaching/mortality thermal threshold (Bhagooli and Sheppard 2012). This situation is further aggravated in the presence of heavy metal contaminants. Sokolova and Lannig (2008) reported synergistic effects of temperature and heavy metal stress. Elevated temperature is known to increase the rate of uptake and accumulation of heavy metals (Cairns et al. 1975; McLusky et al. 1986; Hutchings et al. 1996; Heugens et al. 2002). Symbiodinium exposed to thermal stress demonstrated a reduction in the dark-acclimated maximum quantum yield of PSII compared to the non-stressed ones (Hoegh-Guldberg 2005). In the present study, $\mathrm{Cu}$ and $\mathrm{Pb}$ treatments at $32^{\circ} \mathrm{C}$ significantly reduced the $\mathrm{F}_{\mathrm{v}} / \mathrm{F}_{\mathrm{m}}$, suggesting damage at the level of photosynthetic functioning in Symbiodinium. This phenomenon is mainly attributed to photoinhibition of the PSII (Warner et al. 1999). Within the PSII, numerous components are known to be susceptible to damage by the elevated temperature. These include the oxygen-evolving complex (Havaux 1993), the reaction centre (Heckathorn et al. 1998) as well as the connectivity between the light harvesting complex and the reaction centre of PSII (Schreiber and Armond 1978). Warner et al. (1999) and Lesser and Farrell (2004) have shown that the main site of photoinhibitory damage at the PSII is the D1 proteins, the loss of which is correlated with reductions in $F_{v} / F_{m}$. Bhagooli and Hidaka (2003) suggested that enzymes involved in the synthesis or resynthesis of the D1 protein could be affected by heat stress. Bhagooli (2013) proposed that inhibition of the Calvin-Benson cycle under elevated temperature may suppress the recovery of PSII. This enforces the suggestion that thermal stress exacerbates the pathway of cellular damage that occurs as a result of heavy metal stress, as observed in the present study.

Scleractinian corals have been reported to harbor different genetic types of Symbiodinium, several clades (A,
B, C, D, E, F, G, H, I) (Pochon and Gates 2010). Due to global ocean warming corals tend to change their Symbiodinium communities (Rowan et al. 1997; Baker 2003) with clade D as a thermally tolerant type (Rowan 2004). Members within different Symbiodinium clades can be further subdivided in internal transcribed spacer 2 (ITS2) types exhibiting differential thermal stress photophysiological responses (Bhagooli and Hidaka 2004b; Bhagooli 2009; Bhagooli 2010). Bielmyer et al. (2010) reported variable copper accumulation and susceptibility among three coral species harboring different Symbiodinium clade types, namely A3, C1 and D1a. The coral species harboring Symbiodinium D1a exhibited highest metal tolerance. Kuzminov et al. (2013) demonstrated differential metal toxicity in culture Symbiodinium of clade A1. In the present study, $F$. repanda, which has been reported to be one of the resistant coral species to bleaching events both locally (MattanMoorgawa et al. 2012; Bhagooli and Kaullysing 2018) and worldwide (Marshall and Baird 2000; Loya et al. 2001), was found to host Symbiodinium clade C. Recently, LaJeunesse et al. (2018) detailed the existing sub-cladal types (e.g. ITS2 types) and provided new names to them as distinct species. For instance, they have renamed clade $\mathrm{C}$ Symbiodinium as Cladocopium species. Thus, the differences in responses of Symbiodinium isolates to metal exposure between the present study and the other reports may be partly attributed to difference in Symbiodinium clade types or sub-types. Further studies on the sub-clade types, example ITS2 types, of Symbiodinium in $F$. repanda may provide for detailed comparison with other related studies and sub-cladal variability may imply that the present results for responses to heavy metals may not be generalized for all members of clade C. Some Symbiodinium types such as clade A occurring in some abundant but bleaching susceptible coral species, namely the branching Acropora muricata, occurring near the coast with more fluctuating temperatures, may also have some potential to acclimatize to high temperature regimes and may thus resist bleaching events (Louis et al. 2016). However, the near coast areas are also places where higher levels of both essential and non-essential metals may occur. Consequently, when the sea temperature rises gradually instead of yielding into acclimatization processes that may reduce bleaching incidences the Symbiodinium photophysiology may be negatively affected thus making the corals more vulnerable to thermal events in the coastal waters.

In conclusions, $\mathrm{Cu}(\geq 50 \mu \mathrm{g} / \mathrm{L}), \mathrm{Zn}(\geq 100 \mu \mathrm{g} / \mathrm{L})$ and $\mathrm{Pb}$ $(\geq 30 \mu \mathrm{g} / \mathrm{L})$ decreased the photosynthetic capacity of the Symbiodinium isolates from the coral $F$. repanda with more pronounced effects at higher temperature. The present study showed that a higher temperature enhanced the harmful effect of heavy metals and this lead to marked decline of the photo-physiology of symbionts of the thermally resistant coral Fungia repanda even under short exposure time $(<24-\mathrm{h})$. These findings suggest that coral species which may be thermally robust and are either resistant or resilient to thermal anomaly events, may be rendered photo-physiologically vulnerable to global 
warming-induced mass coral bleaching/mortality events by local coastal heavy-metal contamination. It is important to note that differences in response to both essential and nonessential metals may be specific to the local Symbiodinium clades, and duration of metal exposure. This work provides an impetus for further investigation to determine the effects of heavy metals in the face of global warming.

\section{ACKNOWLEDGEMENTS}

We are grateful to the technical staff of University of Mauritius for their assistance. We extend a sincere thanks to Revtish. The authors are thankful to the then Ministry of Fisheries for granting permission for sample collection.

\section{REFERENCES}

Ali A-H AM, Hamed MA, El-Azim HA. 2011. Heavy metals distribution in the coral reef ecosystems of the Northern Red Sea. Helgol Mar Res 65: $67-80$.

ANZECC [Australian and New Zealand Environment and Conservation Council]. 1992. Australian water quality guidelines for fresh and marine waters.

Australian Institute of Marine Science (AIMS). 2017. Surveys of four coral reefs in Mauritius [online] Available at http: //data.aims.gov.au/metadataviewer/faces/view.xhtml?uuid=af6a6a797203-43eb-ab2e-8fd02379eed7 [Accessed 21 October 2017].

Baker AC. 2003. Flexibility and specificity in coral-algal symbiosis: diversity, ecology, and biogeography of Symbiodinium. Annu Rev Ecol Evol Syst 34: 661-689.

Baker NR, Fernyhough P, Meek IT. 1982. Light dependent inhibition of photosynthetic electron transport by zinc. Physiol Plant 56: 217-222.

Baumann HA, Morrison L, Stengel DB. 2009. Metal accumulation and toxicity measured by PAM-Chlorophyll fluorescence in seven species of marine macroalgae. Ecotoxicol Environ Safety 72: 1063-1075.

Bhagooli R, Hidaka M. 2002. Physiological responses of the coral Galaxea fascicularis and its algal symbiont to elevated temperatures. Galaxea 4: 33-42.

Bhagooli R, Hidaka M. 2003. Comparison of stress susceptibility of in hospite and isolated zooxanthellae among five coral species. J Exp Mar Biol Ecol 291: 181-197.

Bhagooli R, Hidaka M. 2004a. Release of zooxanthellae with intact photosynthetic activity by the coral Galaxea fascicularis in response to high temperature stress. Mar Biol 145 (2): 329-337.

Bhagooli R, Hidaka M. 2004b. Photoinhibition, bleaching susceptibility and mortality in two scleractinian corals, Platygyra ryukyuensis and Stylophora pistillata, in response to thermal and light stresses. Comp Biochem Physiol A: Mol Integr Physiol 137: 547-555.

Bhagooli R, Hidaka M. 2006. Thermal inhibition and recovery of the maximum quantum yield of photosystem II and the maximum electron transport rate in zooxanthellae of a reef-building coral Galaxea, JCRS 8: 1-11.

Bhagooli R, Kaullysing K. 2018 (in press). Seas of Mauritius. Chapter 16 in "World Seas: An Environmental Evaluation Volume II: The Indian Ocean to the Pacific", $2^{\text {nd }}$ eds. Sheppard CCR. Elsevier publication, Dordrecht.

Bhagooli R, Sheppard CRC. 2012. Prediction of recurrences of mass coral bleaching/mortality and vulnerability of reef-building corals to climate change in Mauritius and Japanese waters. University of Mauritius Res J Special issue: Sustainable Marine Environment 18A: 105-121.

Bhagooli R, Taleb-Hossenkhan N. 2012. Thermal spatial heterogeneity and coral bleaching implications for habitat refuges. $12^{\text {th }}$ Int Coral Ree Symp.

http //www.icrs2012.com/proceedings/manuscripts/ICRS2012_9D_1.pdf.

Bhagooli R, Yakovleva I. 2004. Differential bleaching susceptibility and mortality patterns among four corals in response to thermal stress. Symbiosis 37: 121-136.
Bhagooli R. 2009. Symbiont-dependent thermal bleaching susceptibility in two reef-building corals, Stylophora pistillata and Platygyra ryukyuensis. University of Mauritius Res J 15: 608-626.

Bhagooli R. 2010. Photosystem II responses to thermal and/or light stresses of distinct endosymbiotic ITS2 Symbiodinium types isolated from marine animal hosts. J Env Res Dev 5 (1): 117-133.

Bhagooli R. 2013. Inhibition of Calvin-Benson cycle suppresses the repair of photosystem II in Symbiodinium: implications for coral bleaching. Hydrobiologia 714 (1): 183-190.

Bielmyer GK, Grosell M, Bhagooli R, Baker AC, Langdon C, Gillette P, Capo TR. 2010. Differential effects of copper on three species of scleractinian corals and their algal symbionts (Symbiodinium spp.). Aquat Toxicol 97: 125-133.

Bilger W, Björkmann O. 1990. Role of the xanthophylls cycle in photoprotection elucidated by measurements of light-induced absorbance changes, fluorescence and photosynthesis in leaves of Hedera canariensis. Photosyn Res 25: 173-185.

Cairns JJ, Buikema, JAL, Heath AG, Parker BC. 1978. Effects of temperature on aquatic organism sensitivity to selected chemicals. bulletin 106. Virginia Water Resource Research Centre [online] Available at: < http: //vwrrc.vt.edu/pdfs/bulletins/bulletin106.pdf> [Accessed 5 December 2012]

Cairns JJ, Heath AG, Parker BC. 1975. The effects of temperature upon the toxicity of chemicals to aquatic organisms. Hydrobiologia 47: 135-171.

Connan S, Stengel DB. 2011. Impacts of ambient salinity and copper on brown algae: 1. Interactive effects on photosynthesis, growth, and copper accumulation. Aquat Toxicol 104: 94-107.

Daby D. 2006. Coastal pollution and potential biomonitors of metals in Mauritius. Water Air Soil Pollut 174: 63-91.

Davies AG, Sleep, JA. 1979. Photosynthesis in some British coastal waters may be inhibited by zinc pollution. Nature 277: 292-293.

El-Sarraf WM, Taha OE. 1995. Effects of copper on photosynthetic activity and chlorophyll-a content of Chaetoceros Radicans Schütt. Bull High Inst Publ Health 25: 439-446.

El-Sheekh MM. 1993. Quenching of the variable fluorescence induced by zinc in the green alga Chlorella fusca. Braz J Plant Physiol 5: 1-5.

Genty B, Briantais JM and Baker NR. 1989. The relationship between the quantum yield of photosynthetic electron transport and quenching of chlorophyll fluorescence. Biochimica and Biophysica Acta 990: 8792.

Gorbunov MY, Falkowski PG. 2011. Analysis of biophysical, optical and genetic diversity of dod coral reef communities using advanced fluorescence and molecular biology techniques. SERDP Project RC1334 .

Han T, Kang SH, Park JS, Lee HK, Brown MT. 2008. Physiological responses of Ulva pertusa and $U$. armoricana to copper exposure. Aquat Toxicol 86: 176-184

Havaux M. 1993. Rapid photosynthetic adaptation to heat stress triggered in potato leaves by moderately elevated temperatures. Plant Cell Environ 16: 461-467.

Heckathorn SA, Downs CA, Sharkey TD, Coleman JS. 1998. The small, methionine-rich chloroplast heat-shock protein protects photosystem II electron transport during heat stress. Plant Physiol 116: 439-444.

Heugens EH, Hendriks AJ, Dekker T, Van Straalen NM, Admiraal W. 2001. A review of the effects of multiple stressors on aquatic organisms and analysis of uncertainty factors for use in risk assessment. Crit Rev Toxicol 31: 247-284.

Heugens EHW, Hendriks AJ, Dekker T, van Straalen NM, Admiraal W. 2002. A review of the effects of multiple stressors on aquatic organisms and analysis of uncertainty factors for use in risk assessment. Crit Rev Toxicol 31: 247-284.

Hoegh-Guldberg O. 2005. Coral-algal symbiosis in a changing environment. In: Seminar, Interuniversity Underwater Institute, Eilat, Israel, June 3, 2005.

Hu B, Jia X, Hu Jie, Xu D, Xia F,Li Y. 2017. Assessment of Heavy Metal Pollution and Health Risks in the Soil-Plant-Human System in the Yangtze River Delta, China. Intl J Environ. Res Public Health 14: 1042; doi: 10.3390/ijerph14091042

Hussain M, Ahmad MSA, Kausar A. 2006. Effect of lead and chromium on growth, photosynthetic pigments and yield components in mash bean [Vigna Mungo (L.) Hepper]. Pakistan J Bot 38: 1389-1396.

Hutchins DA, Teyssié JL, Boisson F, Fowler SW, Fisher NS. 1996. Temperature effects on uptake and retention of contaminant radionuclides and trace metals by the brittle star Ophiothrix fragilis. Mar Environ Res 41: 363-378. 
Iglesias-Prieto R., Matta JL, Robins WA, Trench RK. 1992 Photosynthetic response to elevated temperature in the symbiotic dinoflagellate Symbiodinium microadriaticum in culture. Proc Natl Acad Sci USA 89: 10302-10305.

Jones RJ, Hoegh-Guldberg O, Larkum AWD, Schreiber U. 1998 Temperature-induced bleaching of corals begins with impairment of the $\mathrm{CO}_{2}$ fixation mechanism in zooxanthellae. Plant Cell Environ 21: 1219-1230.

Joshi MK, Mohanty P. 2004. Chlorophyll $a$ fluorescence as a probe of heavy metal ion toxicity in plants. In: Papageorgiou GC. (eds.) Chlorophyll a Fluorescence: A Signature of Photosynthesis. Springer, Dordrecht.

Kuzminov FI, Brown CM, Fadeev VV, Gorbunov MY. 2013. Effects of metal toxicity on photosynthetic processes in coral symbionts, Symbiodinium spp. J Exp Mar Biol Ecol 446: 216-227.

LaJeuneusse TC, Parkinson JE, Gabrielson PW, Jeong HJ, Reimer JD, Voolstra CR, Santos SR. 2018. Systematic revision of Symbiodiniaceae highlights the antiquity and diversity of coral endosymbionts. Current Biology 28: 2570-2580.

Lamai C, Kruatrachue M, Pokethitiyook P, Upatham ES, Soonthornsarathool V. 2005. Toxicity and accumulation of lead and cadmium in the filamentous green alga Cladophorafracta (O.F. Müller ex Vahl) Kützing: a laboratory study. Sci Asia 31: 121-127.

Lesser MP, Farrell JH. 2004. Exposure to solar radiation increases damage to both host tissues and algal symbionts of corals during thermal stress. Coral Reefs 23: 367-377.

Lesser MP. 1996. Exposure of symbiotic dinoflagellates to elevated temperatures and ultraviolet radiation causes oxidative stress and inhibits photosynthesis. Limnol Oceanogr 41: 271-283.

Lilley RM, Ralph PJ, Larkum AWD. 2010. The determination of activity of the enzyme Rubisco in cell extracts of the dinoflagellate alga Symbiodinium sp. By manganese chemiluminescence and its response to short-term thermal stress of the alga. Plant Cell Environ 33: 995 1004.

Louis YD, Kaullysing D, Gopeechund A, Mattan-Moorgawa S,

Bahorun T, Dyall SD, Bhagooli R. 2016. In hospite Symbiodinium photophysiology and antioxidant responses in Acropora muricata on a coast-reef scale: implications for variable bleaching patterns. Symbiosis 68 (1-3): 61-72.

Loya Y, Sakai K, Yamazato K, Nakano Y, Sambali H, Van Woesik R. 2001. Coral bleaching: the winners and the losers. Ecol Lett 4: 122131.

Main WPL, Ross C, Bielmyer GK. 2010. Copper accumulation and oxidative stress in the sea anemone, Aiptasia pallida, after waterborne copper exposure. Comp Biochem Physiol-C 151: 216-221.

Marshall PA, Baird AH. 2000. Bleaching of corals on the Great Barrier Reef: differential susceptibilities among taxa. Coral Reefs 19 (2): 155-163.

Martínez-Peñalver A, Graña E, Reigosa MJ, Sánchez-Moreiras AM. 2012. The early response of Arabidopsis thaliana to cadmium-and copperinduced stress. Environ Exp Bot 78: 1-9.

Mattan-Moorgawa S, Bhagooli R, Rughooputh SDDV. 2011. Global warming-related photo-physiological stress and bleaching in scleractinian corals at the lagoon of belle mare, Mauritius. In: Workshop on Climate Change, University of Mauritius, Reduit, 13-15 July 2011.

Mattan-Moorgawa S, Bhagooli R, Rughooputh SDDV. 2012. Thermal stress physiology and mortality responses in scleractinian corals of Mauritius. $12^{\text {th }}$ Int Coral Reef Symp. http: //www.icrs2012.com/proceedings/manuscripts/ICRS2012_9A_6.pdf.

McLusky DS, Bryant V, Campbell R. 1986. The effects of temperature and salinity on the toxicity of heavy metals to marine and estuarine invertebrates. Oceanogr Mar Biol 24: 481-520.

Michelmore CL, Verde EA, Weis VM. 2007. Uptake and partitioning of copper and cadmium in the coral Pocillopora damicornis. Aquat Toxicol 85: 48-56.

Miles CD, Brandle JR, Daniel DJ, Chu-Der O, Schnare PD, Uhlik DJ. 1972. Inhibition of PS II in isolated chloroplasts by lead. Plant Physiol 49: 820-825.

Miller M, Cox RP. 1983. Effect of $\mathrm{Zn}^{2+}$ on photosynthetic oxygen evolution and chloroplast manganese. FEBS Letters 155: 331-333.

Mohanty N, Vass I, Demeter S. 1989. Impairment of photosystem 2 activity at the level of secondary quinine acceptor in chloroplasts treated with cobalt, nickel and zinc ions. Physiol Plant 76: 386-390.
National Climatic Data Centre. 2011. Global Climate Change Indicators. [online] Available at: < http: //www.ncdc.noaa.gov/indicators/> [Accessed 3 December 2012]

Oukarroum A, Perreault F, Popovic R. 2012. Interactive effects of temperature and copper on photosystem II photochemistry in Chlorella vulgaris. J Photochem Photobiol B-Biol 110: 9-14.

Parales-Vela HV. González-Moreno S, Montes-Horcasitas C, CaňizaresVillanueva RO. 2007. Growth, photosynthetic and respiratory responses to sub-lethal copper concentrations in Scenedesmus incrassatulus (Chlorophyceae). Chemosphere 67: 2274-2281.

Phillips DJH. 1995. The chemistries and environmental fates of trace metals and organochlorines in aquatic ecosystems. Mar Poll Bull 31: 193-200.

Pinto E, Sigaud-Kutner TCS, Leitão MAS, Okamoto OK, Morse D, Colepicolo P. 2003. Heavy metal-induced oxidative stress in algae. J Phycol 39: 1008-1018.

Pochon X, Gates RD. 2010. A new Symbiodinium clade (Dinophyceae) from soritid foraminifera in Hawai'i. Mol Phyl Evol 56 (1): 492-497.

Rowan R, Knowlton N, Baker AC, Jara J. 1997. Nature 388: 265-269.

Rowan R, Powers D. 1991. Molecular genetic identification of symbiotic dinoflagellates (zooxanthellae). Mar Ecol Prog Ser 71: 65-73.

Rowan R. 2004. Coral bleaching: thermal adaptation in reef coral symbionts. Nature 430: 742.

Ruban AV, Lavaud J, Rousseau B, Guglielmi G, Horton P, Etienne AL. 2004. The super-excess energy dissipation in diatom algae: comparative analysis with higher plants. Photosyn Res 82: 165-175.

Schreiber U, Armond PA. 1978. Heat-induced changes of chlorophyll fluorescence in isolated chloroplasts and related heat damage at the pigment level. Biochim Biophys Acta 502: 138-151.

Sokolova IM, Lannig G. 2008. Interactive effects of metal pollution and temperature on metabolism in aquatic ectotherms: implications of global climate change. Climate Res 37: 181-201.

Stanley Jr GD, Swart PK. 1995. Evolution of the coral-zooxanthellae symbiosis during the Triassic: a geochemical approach. Paleobiology 21: 179-199.

Stiborova M, Doubravova M, Brezinova A, Friedrich A. 1986. Effect of heavy metal ions on growth and biochemical characteristics of photosynthesis of barley (Hordeum vulgare L.). Photosynthetica 20: 418-425.

Strömgren T. 1980. The effect of lead, cadmium, and mercury on the increase in length of five intertidal Fucales. J Exp Mar Biol Ecol 43: 107-119.

Sunda WG, Huntsman SA. 1998. Processes regulating cellular metal accumulation and physiological effects: Phytoplankton as model systems. Sci Total Environ 219: 165-181.

Takahashi S, Milward SE, Fan DY, Chow WS, Badger MR. 2009. How does cyclic electron flow alleviate photoinhibition in Arabidopsis. Plant Physiol 149: 1560-1567.

Ting CS, Owens TG. 1993. Photochemical and nonphotochemical fluorescence quenching processes in the diatom Phaeodactylum tricornutum. Plant Physiol 101: 1323-1330.

Tripathy BC, Mohanty P. 1980. Zinc inhibited electron transport of photosynthesis in isolated chloroplasts. Plant Physiol 66: 1174-1178.

Valavanidis A, Vlachogianni T. 2010. Metal pollution in ecosystems. ecotoxicology studies and risk assessment in the marine environment. Sci Adv Env Toxicol Ecotoxicol [online] Available at: http: //chemtox-ecotox.org/wp-content/uploads/2010/01/02-Metals-17-012010.pdf]. [Accessed 3 December 2012].

Van Assche F, Clijsters H. 1986. Inhibition of photosynthesis in Phaseolus vulgaris by treatment with toxic concentration of zinc: effect on electron transport and photophosphorylation. Physiol Plant 66: 717-721.

Warner M E, Fitt WK, Schmidt GW. 1999. Damage to photosystem II in symbiotic dinoflagellates: a determinant of coral bleaching. Proc Natl Acad Sci USA 96: 8007-8012.

Woolery ML, Lewin RA. 1976. The effects of lead on algae. IV. Effects of $\mathrm{Pb}$ on respiration and photosynthesis of Phaeodactylum trieornutum (Bacillariophyceae) [online] Available at: < http: //link.springer.com/article/10.1007\%2FBF00158712?LI=true\#page$1>$

Yruela I, Montoya G, Picorel R. 1992. The inhibitory mechanism of Cu (II) on the photosystem II electron transport from higher plants. Photosyn Res 33: 227-233. 